\title{
DISTRIBUTION OF BUTTERFLY SPECIES (LEPIDOPTERA: PAPILIONOIDEA) IN THE PROTECTED AREA “MIRUSHA WATERFALLS" IN KOSOVO
}

\author{
Ferdije Zhushi-Etemi ${ }^{1 *}$, Pajtim Bytyqi ${ }^{1}$, \\ Milaim Musliu' ${ }^{2}$ \& Rushan Ceka ${ }^{2}$ \\ 'Department of Biology, Faculty of Mathematics and Natural Sciences, University of Prishtina, \\ Mother Teresa nn, Prishtina 10000, Kosovo \\ ${ }^{2}$ South East European University, Faculty of Contemporary Sciences and Technologies, Ilindenska \\ 335, Tetovo, Macedonia
}

Zhushi-Etemi, F., Bytyqi, P., Musliu, M.\& Ceka, R.: Distribution of butterfly species (Lepidoptera: Papilionoidea) in the protected area "Mirusha waterfalls" in Kosovo. Nat. Croat. Vol. 27, No. 2, 305-314, 2018, Zagreb.

In this paper we present the results of a study on the distribution of butterfly species in the protected area Mirusha Waterfalls in Kosovo, conducted in the period from April to the end of September 2016. No studies on butterfly fauna in this area had been conducted previously.

The survey was organized in 13 sites with different types of habitats, mostly dominated by grassland, natural forest and shrubs. During our study 83 species of butterflies were recorded. The highest diversity (Shannon-Wiener diversity index $\mathrm{H}$ ) was registered at the site Dush i Sverkes which hosted 68 out of 83 recorded species. The highest number of species was Euro-Siberian (ES) followed by EuroOriental (EO), Euro-Meridional (EM) and Holarctic species (Hol). Our results confirm a rich diversity of butterfly fauna influenced by the climate characteristics, geology and plant composition of the studied area. Out of 83 recorded species in our survey, 7 have Near Threatened status in Europe: Carcharodus floccifera (Zeller, 1847); Parnassius mnemosyne (Linnaeus, 1758); Cupido decolorata (Staudinger, 1886); Hipparchia fagi (Scopoli, 1763); Hipparchia statilinus (Hufnagel, 1758); Melitea aurelia (Nickeri, 1850) and Chazara briseis (Linnaeus, 1764).

Key words: Mirusha waterfalls, Kosovo, biodiversity, Lepidoptera, habitat

Zhushi-Etemi, F., Bytyqi, P., Musliu, M.\&Ceka, R.: Rasprostranjenost vrsta leptira (Lepidoptera: Papilionoidea) u zaštićenom području "Slapovi Mirusha" na Kosovu. Nat. Croat. Vol. 27, No. 2, 305-314, 2018, Zagreb.

U radu prikazujemo rezultate istraživanja rasprostranjenosti vrsta leptira u zaštićenom području slapova Mirusha na Kosovu, provedenog u razdoblju od travnja do kraja rujna 2016. Fauna leptira tog područja nije prethodno istraživana. Istraživano je 13 lokaliteta s različitim tipovima staništa, dominirali su travnjaci, šuma i grmlje. Tijekom istraživanja zabilježene su 83 vrste leptira. Najveća raznolikost (Shannon-Wienerov indeks raznolikosti H) bila je na lokalitetu Dush i Sverkes, 68 od 83 zabilježene vrste. Najviše je bilo eurosibirskih vrsta (ES), slijedile su euroorijentalne (EO), euromeridionalne (EM) I holarktičke vrste (Hol). Naši rezultati potvrđuju bogatu bioraznolikost, na koju utječu klimatske značajke, geologija i biljni svijet istraživanog područja. Od 83 zabilježene vrste, 7 ih ima status gotovo ugroženih u Europi: Carcharodus floccifera (Zeller, 1847); Parnassius mnemosyne (Linnaeus, 1758); Cupido decolorata (Staudinger, 1886); Hipparchia fagi (Scopoli, 1763); Hipparchia statilinus (Hufnagel, 1758); Melitea aurelia (Nickeri, 1850) i Chazara briseis (Linnaeus, 1764).

Ključne riječi: slapovi Mirusha, Kosovo, bioraznolikost, Lepidoptera, stanište 


\section{INTRODUCTION}

The first records of butterfly fauna from Kosovo were published by Rebel (1913, 1917a), 1917b; REBel \& ZeRny (1931) and GRAdojević (1930-31). Later on, after almost 50 years without any research into this topic, several publications about the butterfly fauna of Kosovo were published (JAKšić, 1987, 1988, 1998, 1999, 2003, 2006, 2007). According to JAKšIĆ \& ŽIvIĆ (1994-98) the butterfly fauna of Kosovo consists of 171 species. However, the butterfly list is probably not final, as there are still uninvestigated areas in Kosovo, where surveys might result in new species records. Due to many circumstances, in this part of the Balkans, butterfly research in Kosovo had another break, and it continued only after the year 2010 (Zhusнi-Етемі et al., 2016, 2017)

The aim of this paper is to present the results of the first investigation of butterfly fauna in the protected area Mirusha waterfalls in Kosovo.

\section{STUDY AREA}

A Natural Monument of High Importance, Mirusha Waterfalls is one of the most beautiful and most interesting areas of nature in Kosovo.Flowing through Mirusha Park is the Mirusha River, from which the park got its name. With a surface of 598.4 ha, this area represents a rare natural phenomenon of special natural, scientific, cultural and touristic importance. It is positioned in the central part of the country, in the territory of three municipalities: Klina, Malisheva and Rahoveci. The Nature Park is located in the south of the Gremnik mountains, on both sides of the Mirusha River, from the beginning of the canyon, up to the discharge into the White Drini River, around $2 \mathrm{~km}$ from villages of Dush, Grapc and Llapqeva and the Hill of Dushi. The elevation ranges from 340 meters to 600 meters above sea level.

The most interesting part of the park is the canyon where the Mirusha River flows and creates 16 karst lakes and 12 waterfalls arranged one after another in cascades.

Regarding the geological structure, it consists of ultra-basic rocks and volcanic-sedimentary formations of Jurassic age, and carbonates from the Lower and Upper Cretaceous. The geological structure of Mirusha canyon is mainly composed of Mesozoic limestone cliffs with a tendency to drop in the direction of the water flow (MESP, 2012)

Besides the waterfalls and lakes, characteristic forms are also caves with different shapes and sizes, cracks and other rock phenomena created as a result of the geological past, the effects of erosion, water and other factors.

The climate in the area of Mirusha Park is mild continental with influence of the Mediterranean climate. As a result of this climate, but also of the low industrial development and traditional farming, the area is quite rich in plant species and associations. The flora is composed of 14 plant associations, 5 of them of endemic character. The largest part of the area is covered by the association of oak (Ass. Quercetum farnetto - Cerris scardicum Krasniqi 1968), which is one of the most widespread associations in Kosovo. The characteristic of this region is the presence of habitats like: white willow (Salicetum albae fragilis), red willow (Salicetum purpurea), black alder (Alnetum glutinosae), oak (Quercetum farnetto-Cerris scardicum and Quercetum pubescentis-cerris), juniper (Astero-Juniperetum oxycedri), and other associations Polygalo-Genistetum hassertianae, Hyperico-Euphorbietum glabriflorae, Potentilla-Fumaretum bonopartei, Salvio-Scorsoneretum villosae, Echinario-Convolvuletum althaeoides, Onosmo-Scabietosum fumaroides, Vitici-Tarmaricetum dalmaticae (REXHEPI, 1974, 1994) 
Tab. 1. Surveyed localities with habitat types, geographic coordinates, and altitude

\begin{tabular}{|c|c|c|c|}
\hline Locality and habitat types & $\mathbf{N}$ & E & altitude \\
\hline $\begin{array}{l}\text { L1. Volljakë - close to the Restaurant at the entrance of Mirusha } \\
\text { Park - wet mesotrophic grassland }\end{array}$ & $42^{\circ} 31^{\prime} 31^{\prime \prime}$ & $20^{\circ} 33^{\prime} 46^{\prime \prime}$ & $366 \mathrm{~m}$ \\
\hline $\begin{array}{l}\text { L2. Mrasor - near the electric power lines - unmanaged mesic } \\
\text { grassland }\end{array}$ & $42^{\circ} 30^{\prime} 45^{\prime \prime}$ & $20^{\circ} 33^{\prime} 39^{\prime \prime}$ & $439 \mathrm{~m}$ \\
\hline $\begin{array}{l}\text { L3. Mrasor - agriculturally improved, re-seeded and heavily } \\
\text { fertilized grassland, arable land with unmixed crops }\end{array}$ & $42^{\circ} 30^{\prime} 42^{\prime \prime}$ & $20^{\circ} 33^{\prime} 44^{\prime \prime}$ & $459 \mathrm{~m}$ \\
\hline L4. Llapqevë - dry grassland with sparse vegetation and screes & $42^{\circ} 30^{\prime} 15^{\prime \prime}$ & $20^{\circ} 34^{\prime} 21^{\prime \prime}$ & $509 \mathrm{~m}$ \\
\hline L5. Llapqevë - hot, dry grassland, vegetation $>30 \%$ & $42^{\circ} 30^{\prime} 1^{\prime \prime}$ & $20^{\circ} 34^{\prime} 57^{\prime \prime}$ & $523 \mathrm{~m}$ \\
\hline $\begin{array}{l}\text { L6. Llapqevë - broadleaved deciduous shrubs and low trees } \\
\text { combined with screes }\end{array}$ & $42^{\circ} 31^{\prime} 10^{\prime \prime}$ & $20^{\circ} 34^{\prime} 26^{\prime \prime}$ & $471 \mathrm{~m}$ \\
\hline $\begin{array}{l}\text { L7. Llapqevë - on the way to the first waterfall - woodland } \\
\text { clearings, grassland with shrubs }\end{array}$ & $42^{\circ} 31^{\prime} 8^{\prime \prime}$ & $20^{\circ} 34^{\prime} 22^{\prime \prime}$ & $391 \mathrm{~m}$ \\
\hline $\begin{array}{l}\text { L8. Dush i Sverkes - open eutrophic flowery grassland with } \\
\text { herbaceous plants }\end{array}$ & $42^{\circ} 31^{\prime} 26^{\prime \prime}$ & $20^{\circ} 34^{\prime} 35^{\prime \prime}$ & $379 \mathrm{~m}$ \\
\hline $\begin{array}{l}\text { L9. Dush i Sverkes - near the first waterfall and lake - stony lake } \\
\text { shore, sheltered wet grassland; basic and ultra-basic inland } \\
\text { cliffs }\end{array}$ & $42^{\circ} 31^{\prime} 26^{\prime \prime}$ & $20^{\circ} 34^{\prime} 55^{\prime \prime}$ & $383 \mathrm{~m}$ \\
\hline $\begin{array}{l}\text { L10. Dush i Sverkes - rough terrain over the first waterfall } \\
\text { - calcareous grassland }\end{array}$ & $42^{\circ} 31^{\prime} 36^{\prime \prime}$ & $20^{\circ} 34^{\prime} 57^{\prime \prime}$ & $424 \mathrm{~m}$ \\
\hline L11. Volljakë - wet mesotrophic grassland & $42^{\circ} 31^{\prime} 25^{\prime \prime}$ & $20^{\circ} 33^{\prime} 46^{\prime \prime}$ & $416 \mathrm{~m}$ \\
\hline L12. Volljakë - wet meadow, woodland clearings & $42^{\circ} 31^{\prime} 14^{\prime \prime}$ & $20^{\circ} 33^{\prime} 59^{\prime \prime}$ & $364 \mathrm{~m}$ \\
\hline L13. Llapqevë - Broadleaved deciduous woodland & $42^{\circ} 31^{\prime} 22^{\prime \prime}$ & $20^{\circ} 34^{\prime} 36^{\prime \prime}$ & $440 \mathrm{~m}$ \\
\hline
\end{tabular}

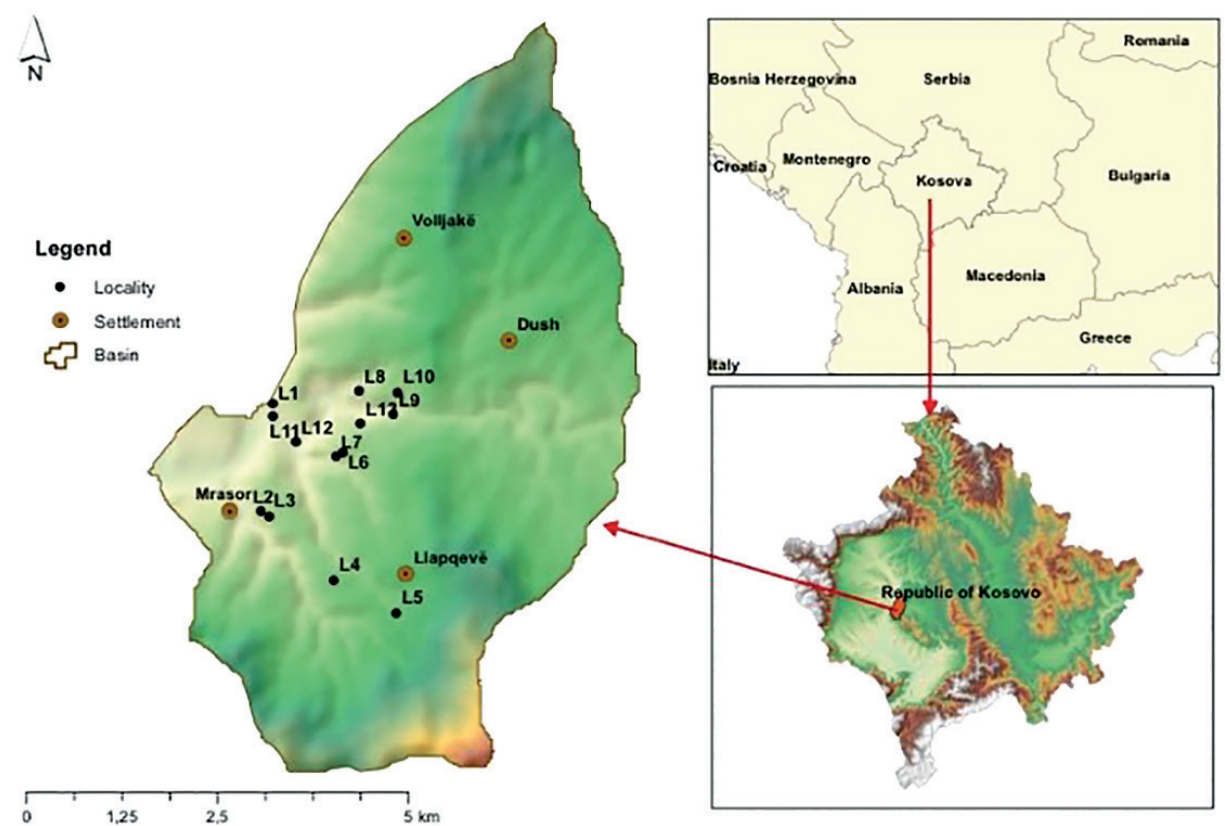

Fig. 1. Map of the surveyed area. 


\section{METHODS}

Butterflies were collected two times per month with an entomological net in the period from April to the end of September, 2016, at 13 localities with butterfly-rich habitats (Fig. 1). A permit for the research was issued by the Ministry of Environment and Spatial Planning of Kosovo. During this survey 1704 butterfly specimens were examined. Most of the butterflies were identified in the field (Tolman \& Lewington, 2008) and released, except few species that were identified in the laboratory with the help of stereomicroscope, based on morphometric characteristics of the wings. The genitalia for some problematic species were not checked.

The taxonomy follows NieUKERKEN et al. (2011), nomenclature follows Fauna Europaea (DE JoNG et al., 2014). The IUCN categories are taken from European Red List of Butterflies (van SwaAy et al., 2010). All the preserved material is deposited at the Department of Biology, FMNS, University of Prishtina.

The zoogeographical categorization is based on KuDRNa (2015). The ecological metrics (species richness-S; abundance-N; and Shannon-Wiener diversity index $\mathrm{H}$ ) were calculated using ComEcoPaC (Drozd, 2010).

\section{RESULTS AND DISCUSSION}

During our survey in the Mirusha waterfalls area we recorded 83 species (Tab. 2), representing 40\% of the butterfly fauna of Kosovo (JAKšić \& Živić, 1994/1998).

As shown in Tab. 3, each of the surveyed localities is quite rich in butterfly diversity, hosting more than $50 \%$ of all recorded species. However, the species richness (S) is the highest in L11 where 71 out of 83 species were recorded. This locality was dominated by grassland habitat with screes and was also the richest in terms of abundance of butterflies. The Shannon Wiener diversity index $\mathrm{H}$ was the highest $(\mathrm{H}=5.935)$ in L8. The poorest in butterfly numbers/abundance was locality 10, with basic and ultra basic inland cliffs.

Tab. 2. List of recorded butterfly species in the surveyed area, zoogeographical characteristic-faunistic groups and the locality where the species was recorded

\begin{tabular}{|c|l|c|l|c|}
\hline & $\begin{array}{l}\text { LEPIDOPTERA } \\
\text { PAPILIONOIDEA }\end{array}$ & $\begin{array}{c}\text { Faunal Elements } \\
\text { (KuDRNA } \text { et al., 2015) }\end{array}$ & $\begin{array}{l}\text { Locality where the species is } \\
\text { recorded }\end{array}$ & $\begin{array}{c}\text { IUCN } \\
\text { Status }\end{array}$ \\
\hline & HESPERIIDAE & Med & $5,6,9,10$ & NT \\
\hline 1 & Carcharodus alceae (Esper,1780) & EO & 5,68, & NT \\
\hline 2 & Carcharodus floccifera (Zeller, 1847) & Hol & $2,3,4,5,6,7,8,12$ & LC \\
\hline 3 & Hesperia comma (Linnaeus, 1758) & ES & $3,4,11,13$ & LC \\
\hline 4 & Ochlodes sylvanus ( Esper, 1761) & EO & $1,2,3,4,5,6,7,8,9,10,11,12,13$ & LC \\
\hline 5 & Pyrgus armoricanus (Oberthür, 1910) & ES & $1,2,3,4,5,6,7,8,9,10,11,12,13$ & LC \\
\hline 6 & Pyrgus malvae (Linnaeus, 1758) & EO & $2,4,5,6,7$ & LC \\
\hline 7 & Pyrgus sidae (Esper, 1784) & EO & $3,4,11,13$ & LC \\
\hline 8 & Spialia orbifer (Hübner, 1823) & & $1,2,3,4,5,6,7,8,12,13$ & LC \\
\hline & PAPILIONIDAE & ES & $1,2,3,4,6,11,12$ & LC \\
\hline 9 & Iphiclides podalirius (Linnaeus, 1758) & ES & $8,11,12$ & NT \\
\hline 10 & Papilio machaon Linnaeus, 1758 & EO & $1,3,4,8,11$ & LC \\
\hline 11 & Parnassius mnemosyne (Linnaeus, 1758) & & & \\
\hline 12 & $\begin{array}{l}\text { Zerynthia polyxena (Denis \& Schiffermüller, } \\
\text { 1775) }\end{array}$ & & & \\
\hline
\end{tabular}




\begin{tabular}{|c|c|c|c|c|}
\hline & $\begin{array}{l}\text { LEPIDOPTERA } \\
\text { PAPILIONOIDEA } \\
\end{array}$ & $\begin{array}{l}\text { Faunal Elements } \\
\text { (KudRNA et al., 2015) }\end{array}$ & $\begin{array}{l}\text { Locality where the species is } \\
\text { recorded }\end{array}$ & $\begin{array}{l}\text { IUCN } \\
\text { Status }\end{array}$ \\
\hline & PIERIDAE & & & \\
\hline 13 & Anthocharis cardamines (Linnaeus, 1758) & ES & $1,2,3,4,5,6,7,8,9,10,11,12,13$ & LC \\
\hline 14 & Aporia crataegi (Linnaeus, 1758) & ES & $1,2,3,4,5,8,11,12$ & LC \\
\hline 15 & Colias alfacariensis (Ribbe, 1905) & EO & $1,2,3,4,5,6,7,8,9,10,11,12,13$ & LC \\
\hline 16 & Colias crocea (Fourcroy, 1758) & $\mathrm{EO}$ & $1,2,3,4,5,6,7,8,9,10,11,12,13$ & LC \\
\hline 17 & Gonepteryx rhamni (Linnaeus, 1758) & ES & $1,2,3,4,5,6,7,8,9,10,11,12,13$ & $\mathrm{LC}$ \\
\hline 18 & Leptidea sinapis/juvernica (Linnaeus, 1758) & ES & $1,2,3,4,5,8,11,12$ & LC \\
\hline 19 & Leptidea duponcheli (Staudinger, 1871) & EO & $1,2,3,4,5,8,11,12$ & LC \\
\hline 20 & Euchloe ausonia (Hübner, 1803) & Med & $1,2,3,4,8,12$ & LC \\
\hline 21 & Pieris brassicae (Linnaeus, 1758) & ES & $1,2,3,4,8,12$ & LC \\
\hline 22 & Pieris ergane (Geyer, 1828) & $\mathrm{EO}$ & $1,2,3,4,5,8,11,12$ & LC \\
\hline 23 & Pieris napi (Linnaeus, 1758) & ES & $1,2,3,4,5,8,11,12$ & $\mathrm{LC}$ \\
\hline 24 & Pieris mannii (Mayer, 1851) & $\mathrm{EO}$ & $1,2,3,4,5,8,11,12$ & LC \\
\hline 25 & Pieris rapae (Linnaeus, 1758) & Hol & $1,2,3,4,5,8,11,12$ & LC \\
\hline \multirow[t]{2}{*}{26} & Pontia edusa (Fabricius, 1777) & ES & $1,3,4,8,11$ & LC \\
\hline & LYCAENIDAE & & & \\
\hline 27 & Aricia agestis (Denis \& Schiffermüller, 1775) & ES & $1,2,4,5,8,11$ & LC \\
\hline 28 & Callophrys rubi (Linnaeus, 1758) & ES & $1,2,3,4,5,6,7,8,9,10,11,12,13$ & LC \\
\hline 29 & Celastrina argiolus (Linnaeus, 1758) & ES & 11 & $\mathrm{LC}$ \\
\hline 30 & Cupido argiades (Pallas, 1771) & Hol & $1,2,4,5,8,11$ & $\mathrm{LC}$ \\
\hline 31 & Cupido decolorata (Staudinger, 1886) & EM & 8,12 & NT \\
\hline 32 & Cupido minimus (Fuessly, 1775) & ES & $1,2,3,4,5,6,7,8,9,10,11,12,13$ & $\mathrm{LC}$ \\
\hline 33 & Glaucopsyche alexis (Poda, 1761) & ES & $1,2,3,4,5,6,7,8,9,10,11,12,1$ & LC \\
\hline 34 & Lampides boeticus (Linnaeus, 1767) & Tro & 11 & LC \\
\hline 35 & Lycaena alciphron (Rottemburg, 1775) & $\mathrm{EO}$ & $1,3,4,8,11,12$ & LC \\
\hline 36 & Lycaena dispar (Haworth, 1802) & ES & $1,2,3,4,5,6,7,8,9,10,11,12,13$ & LC \\
\hline 37 & Lycaena phlaeas (Linnaeus, 1761) & Hol & $1,2,3,4,5,6,7,8,10,11,12,13$ & $\mathrm{LC}$ \\
\hline 38 & Lycaena tityrus (Poda, 1761) & ES & $1,3,4,8,11,12$ & LC \\
\hline 39 & Lycaena thersamon (Esper, 1784 ) & EO & $1,3,4,8,11,12$ & LC \\
\hline 40 & Plebejus argus (Linnaeus, 1758) & ES & $1,8,9,10,11,12$ & LC \\
\hline 41 & Plebejus argyrognomon (Bergsträsser, 1779) & ES & $1,2,3,4,5,6,7,8,9,10,11,12,13$ & LC \\
\hline 42 & Polyommatus amandus (Schneider, 1792) & ES & $1,2,3,4,5,6,7,8,10,11,12,13$ & LC \\
\hline 43 & Polyommatus bellargus (Rottemburg, 1775) & $\mathrm{EO}$ & $1,2,3,4,5,6,7,8,9,10,11,12,13$ & LC \\
\hline 44 & Polyommatus coridon (Poda, 1761) & $\mathrm{EO}$ & $1,2,3,4,5,6,7,8,9,10,11,12,13$ & $\mathrm{LC}$ \\
\hline 45 & $\begin{array}{l}\text { Polyommatus daphnis (Denis \& } \\
\text { Schiffermüller, 1775) }\end{array}$ & $\mathrm{EO}$ & $1,2,3,4,5,6,7,8,9,10,11,12,13$ & LC \\
\hline 46 & Polyommatus icarus (Rottemburg, 1775) & ES & $1,2,3,4,5,6,7,8,9,10,11,12,13$ & LC \\
\hline \multirow[t]{2}{*}{47} & Scolitantides orion (Pallas, 1771) & ES & 9 & LC \\
\hline & NYMPHALIDAE & & & \\
\hline 48 & Aglais io (Linnaeus, 1758) & ES & $1,2,3,4,5,6,7,8,9,10,11,12,13$ & LC \\
\hline 49 & Aglais urticae (Linnaeus, 1758) & ES & $3,4,11$ & $\mathrm{LC}$ \\
\hline 50 & Apatura ilia (Denis \& Schiffermüller, 1775) & ES & 8,11 & $\mathrm{LC}$ \\
\hline 51 & Araschnia levana (Linnaeus, 1758) & ES & 8,11 & LC \\
\hline 52 & $\begin{array}{l}\text { Arethusana arethusa (Denis \& } \\
\text { Schiffermüller, 1775) }\end{array}$ & $\mathrm{EO}$ & $1,2,3,4,5,6,7,8,9,10,11,12,13$ & LC \\
\hline 53 & Argynnis aglaja (Linnaeus, 1758) & ES & $1,2,3,4,5,6,7,8,9,10,11,12,13$ & $\mathrm{LC}$ \\
\hline 54 & Argynnis niobe (Linnaeus, 1758) & ES & $1,2,3,4,5,6,7,8,9,10,11,12,13$ & LC \\
\hline 55 & $\begin{array}{l}\text { Argynnis pandora (Denis \& Schiffermüller, } \\
\text { 1775) }\end{array}$ & $\mathrm{EO}$ & $1,2,3,4,5,6,7,8,9,10,11,12,13$ & $\mathrm{LC}$ \\
\hline
\end{tabular}




\begin{tabular}{|c|c|c|c|c|}
\hline & $\begin{array}{l}\text { LEPIDOPTERA } \\
\text { PAPILIONOIDEA }\end{array}$ & $\begin{array}{l}\text { Faunal Elements } \\
\text { (KudRNA et al., 2015) }\end{array}$ & $\begin{array}{l}\text { Locality where the species is } \\
\text { recorded }\end{array}$ & $\begin{array}{l}\text { IUCN } \\
\text { Status }\end{array}$ \\
\hline 56 & Argynnis paphia (Linnaeus, 1758) & ES & $1,2,3,4,5,6,7,8,9,10,11,12,13$ & LC \\
\hline 57 & Boloria dia (Linnaeus, 1767) & ES & $1,2,3,4,5,6,7,8,9,10,11,12,13$ & LC \\
\hline 58 & Boloria euphrosyne (Linnaeus, 1758) & ES & $1,2,3,4,5,6,7,8,9,10,11,12,13$ & LC \\
\hline 59 & Brenthis daphne (Bergsträsser, 1780) & ES & $1,2,3,4,5,6,7,8,9,10,11,12,13$ & $\mathrm{LC}$ \\
\hline 60 & $\begin{array}{l}\text { Brenthis hecate (Denis \& Schiffermüller, } \\
1775 \text { ) }\end{array}$ & ES & $1,2,3,4,5,6,7,8,9,10,11,12,13$ & $\mathrm{LC}$ \\
\hline 61 & Brintesia circe (Fabricius, 1775) & $\mathrm{EO}$ & $6,7,8,11,12$ & LC \\
\hline 62 & Chazara briseis (Linnaeus ${ }_{\mathbf{L}}$ 1764) & ES & $2,5,6,11,12,13$ & NT \\
\hline 63 & Coenonympha pamphilus (Linnaeus, 1758) & $\mathrm{EO}$ & $1,2,3,4,5,6,7,8,9,10,11,12,13$ & $\mathrm{LC}$ \\
\hline 64 & Hipparchia fagi/syriaca (Scopoli, 1763) & EM & $1,2,6,7,12,13$ & NT \\
\hline 65 & Hipparchia statilinus (Hufnagel, 1758) & EM & $1,2,6,7,12,13$ & NT \\
\hline 66 & $\begin{array}{l}\text { Hipparchia volgensis (Mazochin - } \\
\text { Porshnjakov, 1952) }\end{array}$ & EM & $1,2,6,7,12,13$ & $\mathrm{LC}$ \\
\hline 67 & Hyponephele lupina (Costa, 1836) & ES & $1,2,3,4,5,6,7,8,9,10,11,12,13$ & LC \\
\hline 68 & Issoria lathonia (Linnaeus, 1758) & ES & $1,2,3,4,5,6,7,8,9,10,11,12,13$ & LC \\
\hline 69 & Kirinia roxelana (Cramer, 1777) & $\mathrm{EO}$ & $1,2,6,7,9,12,13$ & LC \\
\hline 70 & Lasiommata megera (Linnaeus, 1767) & $\mathrm{EO}$ & 9,11, & LC \\
\hline 71 & Limenitis reducta Staudinger, 1901 & EO & $1,2,3,4,5,6,7,8,9,10,11,12,13$ & LC \\
\hline 72 & Maniola jurtina (Linnaeus, 1758) & ES & $1,2,3,4,5,6,7,8,9,10,11,12,13$ & LC \\
\hline 73 & Melanargia galathea (Linnaeus, 1758) & EO & $1,2,3,4,5,6,7,8,9,10,11,12,13$ & $\mathrm{LC}$ \\
\hline 74 & Melitaea athalia (Rottemburg, 1775) & ES & $2,6,7,9,12,13$ & $\mathrm{LC}$ \\
\hline 75 & Melitaea aurelia Nickerl, 1850 & EO & 8 & NT \\
\hline 76 & Melitaea cinxia (Linnaeus, 1758) & ES & $1,2,3,4,5,6,7,8,9,10,11,12,13$ & LC \\
\hline 77 & Melitaea didyma (Esper, 1778) & ES & $2,3,4,6,7,8,9,10,11,12,13$ & $\mathrm{LC}$ \\
\hline 78 & $\begin{array}{l}\text { Melitaea phoebe (Denis \& Schiffermüller, } \\
1775 \text { ) }\end{array}$ & ES & $1,2,3,4,5,6,7,8,9,10,11,12,13$ & $\mathrm{LC}$ \\
\hline 79 & $\begin{array}{l}\text { Melitaea trivia (Denis \& Schiffermüller, } \\
\text { 1775) }\end{array}$ & EO & $1,2,3,4,5,6,7,8,9,10,11,12,13$ & LC \\
\hline 80 & Polygonia c-album (Linnaeus, 1758) & ES & $1,2,3,4,5,6,7,8,9,10,11,12,13$ & $\mathrm{LC}$ \\
\hline 81 & Pyronia tithonus (Linnaeus, 1767) & EM & $1,2,3,4,5,6,7,8,9,10,11,12,13$ & $\mathrm{LC}$ \\
\hline 82 & Vanessa atalanta (Linnaeus, 1758) & Hol & $1,2,3,4,5,6,7,8,9,10,11,12,13$ & LC \\
\hline 83 & Vanessa cardui (Linnaeus, 1758) & Cos & $1,2,3,4,5,6,7,8,9,10,11,12,13$ & LC \\
\hline
\end{tabular}

Tab. 3. Species richness, abundance and Shannon-Wiener diversity index $(\mathrm{H})$ in surveyed localities

\begin{tabular}{|l|c|c|c|c|c|c|c|c|c|c|c|c|c|}
\hline Indices & L1 & L2 & L3 & L4 & L5 & L6 & L7 & L8 & L9 & L10 & L11 & L12 & L13 \\
\hline $\begin{array}{l}\text { S-total number of species } \\
\text { species richness) }\end{array}$ & 65 & 63 & 63 & 66 & 55 & 54 & 50 & 68 & 48 & 45 & 71 & 68 & 51 \\
\hline $\begin{array}{l}\text { N-total number of } \\
\text { individuals / abundance }\end{array}$ & 159 & 150 & 134 & 147 & 110 & 118 & 127 & 169 & 123 & 81 & 172 & 122 & 92 \\
\hline $\begin{array}{l}\text { H-Shannon-Wiener diversity } \\
\text { index }\end{array}$ & 5.85 & 5.84 & 5.78 & 5.90 & 5.61 & 5.53 & 5.45 & 5.93 & 5.31 & 5.25 & 5.84 & 5.92 & 5.50 \\
\hline
\end{tabular}

In a zoogeographic aspect -faunistic composition (Tab. 2) $52.43 \%$ or 43 of the recorded species are-Euro-Siberian (ES); $31.7 \%$ or 26 species are Euro-Oriental (EO); $6.09 \%$ (5 species) are Euro-Meridional (EM); 6.09\% (5 species) are Holarctic ( $\mathrm{Hol}$ ) and the rest $3.63 \%$ are Cosmopolitan, Mediterranean and Tropical. 
The species that were recorded only in one of the sites are Lampides boeticus (Linnaeus, 1767) at L9, Scolitantides orion (Pallas, 1771), and Celastrina argiolus (Linnaeus, 1758) at L11.

The two species that were most often dominant in this survey were Coenonympha pamphilus and Hyponephele lupina, followed by Melitea phoebe and M. trivia. Among Lycaenidae the most abundant were Polyommatus icarus and Polyommatus bellargus.

According to the Red Data List of European Butterflies (VAN SwaAy et al., 2010) among the 83 recorded species, 7 are near threatened (NT): Carcharodus floccifera, Parnassius mnemosyne, Cupido decolorata, Hipparchia fagi, Hipparchia statilinus, Chazara briseis and Melitaea aurelia.

Lycaena dispar, Parnassius mnemosyne and Zerynthia polyxena are three species listed in Annex IV of the Habitats Directive and Annex II of the Bern Convention and will require more attention from the competent authorities of the country responsible for the conservation measures to protect listed species and their habitats. The habitats of Lycaena dispar (Haworth, 1802) are boggy margins of lakes and rivers, ditches and canals (Tolman \& Lewington, 1997). The main threats for this species are the changes in land use and the drainage of wetlands. In Kosovo L. dispar is recorded in several localities: in Sharri Mountain National Park (JAKšıć, 1998); in Bjeshket e Nemuna National Park (JAKšić, 2006), and in Shkoza Massif (Zhushi-Eтемi et al., 2016)

Another interesting species is Cupido decolorata (Staudinger, 1886), which in our research was recorded in two localities with a small number of specimens. In our survey this species was recorded in a wet flowery grassland and in woodland clearings. The existing data for the presence of this species in our country are from Sharri Mountain National Park (JAKšıć, 1998) and from the Shkoza Massif in tjhe central part of the country (ZhusHi-Eтемi et al., 2016)

Compared to other protected areas in Kosovo, Mirusha has a relatively modest butterfly fauna. According to existing data, 147 butterfly species are reported from Sharri National Park on both sides of the Kosovo-Macedonia border (JAKšIć, 1998); 98 species in Mt. Pashtrik (JaKšıć, 2007); 110 species from Germia Regional Park in Prishtina and 139 in Mt. Bjeshkët e Nemuna/Prokletije (JAKšıć, 2006), which nowadays has national park status.

\section{CONCLUSION}

In taxonomic terms, the 1704 specimens examined during our survey belong to 5 families, 49 genera and 83 species. The richest in diversity is the family Nymphalidae with 36 recorded species $(43.37 \%)$, followed by Lycaenidae with 21 species $(26.30 \%)$, Pieridae $14(16.86 \%)$, Hesperiidae with 8 recorded species $(9.63 \%)$ and Papilionidae with 4 species $(4.81 \%)$.

In comparison with the fauna of other studied regions, the number of butterfly species recorded in the Mirusha waterfall area looks modest, but it should be noted that it is based on a single study, whereas in the other regions the survey period was much longer, resulting in a higher number of recorded species. In our opinion, the species list from this survey should prompt the national authorities to start immediately with conservation measures for the protection of the seven recorded species that are Near Threatened (NT) in Europe as well as two other species, Lycaena dispar and Zerynthia polyxena, which are not threatened but are listed in Habitat directives and are protected in Europe. 
We can conclude that the number of recorded butterfly species in this survey indicates a potentially rich butterfly fauna in the protected area Mirusha waterfalls. However, further research in this area should give more information about the butterfly diversity as well as about the ecological, geological, climate and floristic factors that influence the species composition. We would suggest that the authorities restrict changes in land use, especially the building of hotels and restaurants inside the protected area that can have an impact on butterfly habitats.

Received June 8, 2017

\section{REFERENCES}

Gradojević, M., 1930/31: Prilog lepidopterskoj fauni Jugoslavije. Leptirovi Srbije-Diurna. Glasnik Jugoslovenskog Entomološkog Društva, V-VI, 1-2, 89-96.

de Jong, Y., Verbeek, M., Michelsen, V., Per De Place, B., Los, W., Steeman, F., Bailly, N., Basire, C., Chylarecki, P. et al., 2014: Fauna Europaea - all European animal species on the web. Biodiversity Data Journal 2, e4034. doi: 10.3897/BDJ.2.e4034.

Drozd, P., 2010: ComEcoPaC - Community Ecology Parameter Calculator. Version 1. Available from: http://prf.osu.cz/kbe/dokumenty/sw/ComEcoPaC/ComEcoPaC.xls.

European Commission, 1992: Council Directive 92/43/EEC of 21May 1992 on the Conservation of Natural Habitats and of Wild Fauna and Flora. (OJ L206, 22.vii.1992, p.7), last amended 23.ix.2003 (L236, pp. 33). Council of Europe, Strasbourg, 66 pp.

JaKšić, P., 1987: Specifični elementi faune Lepidoptera nekih kosovskih klisura. Priroda Kosova, Priština, 6, 93-107.

JAKšIĆ, P., 1998: Dnevni leptiri (Lepidoptera: Hesperioidea i Papilionoidea) Šar-planine. [The butterflies of Šar-planina Mt. (Lepidoptera: Hesperioidea \& Papilionoidea)]. Beograd. Zaštita prirode, 50, 229-252

JAKŠIĆ, P., 1999: Distribution of butterfly communities (Lepidoptera: Hesperioidea and Papilionoidea) in plant communities over the Jažinačko jezero lake region on Šar-planina Mt. / Distribucija zajednica dnevnih leptira (Lepidoptera: Hesperioidea \& Papilionoidea) u biljnim zajednicama na širem području Jažinačkih jezera na Sar-planini. The University Thought, Natural Sciences Priština, 5(2), 71 pp.

JAKšıć, P., 2006: Dnevni leptiri Prokletija (Lepidoptera: Hesperioidea i Papilionoidea). [The butterflies of the former Yugoslavian Prokletije Mt. (Lepidoptera: Hesperioidea i Papilionoidea)]. Zbornik radova o fauni Srbije, SANU, Beograd. Odeljenje hemijskih i bioloških nauka, Knjiga VII, 87-104.

JAKšıć, P. \& Žıvić, N., 1994/1998: The butterflies of the Kosovo and Metohija in South Srbija (Lepidoptera: Hesperioidea and Papilionoidea), Glasnik Prirodnjačkog Muzeja u Beogradu, B 49-50.

Kudrna, o., Pennerstorfer, J. \& Lux, K., 2015: Distribution atlas of European butterflies and skippers. Schwanfeld, Wissenschaftlicher Verlag Peks i.K.

Nieukerken, V., Kaila, L., Kitching, I.J., Kristensen, N.P., Lees, D.C., Minet, J. et al., 2011. Order Lepidoptera Linnaeus, 1758. In: Zhang, Z. Q. (Ed.) Animal biodiversity: An outline of higher level classification and survey of taxonomic richness. Zootaxa, 3148(1), 211-221.

Rebel, H., 1913: Studien über die Lepidopterenfauna der Balkanländer, Teil III. Sammelerrgebnisse aus Montenegro, Albanien, Mazedonien und Trazien. Annalen des K.K. Naturhistorischen Hofmuseums, Wien 27, 281-334.

Rebel, H., 1917a: Neue Lepidopterenfunde in Nordalbanien, Mazedonien und Serbien. Jahresber. des Naturwissenschaftlichen Orientverein, 21, 17-24.

ReBEL, H., 1917b: Lepidopteren aus Neumontenegro. Kaiserliche Akademie der Wissenschaften in Wien $126,765-788$.

Rebel, H. \& Zerny, H., 1931: Die Lepidopterenfauna Albaniens. Denkschriften der Akademie der Wissenschaften in Wien, Mathematisch-Naturwissenschaftliche klasse 103. Band

RexhEPI, F., 1974: Kontribut për njohjen e florës së serpentinës në Kosovë. Fac. of Nat. Sci. Buletin 53-69.

RexhepI, F., 1994: The vegetation of Kosova (in Albanian). Monography, Prishtina, 165 p.

Tolman, T. \& Lewington, R., 1997: Butterflies of Britain \& Europe. Harper Collins Publishers, London, $320 \mathrm{pp}$.

Tolman, T. \& Lewington, R., 2008: Collins butterfly guide. Harper Collins Publishers, London, 384 pp. 
Van Swaay, C., Cuttelod, A., Collins, S., Maes, D., Munguira, M.L., Šašić, M. et al., 2010: European red List of Butterflies, Luxembourg: Publications office of the European Union, 47

Zhushi-Etemi, F., Bytyqi, P., Ismaili, M., Musliu, M., 2016: Contribution to the knowledge of the Lycaenidae fauna of central part of Kosovo. Macedonian Journal of Ecology and Environment, 18(2), 29-36.

Zhushi, F., Bytyqi, P., Ismaili, M., Musliu, M., 2017: Contribution to the knowledge of Nymphalidae fauna (Lepidoptera: Rhopalocera) in Kosovo. Trakia Journal of Sciences, 2, 101-105. doi:10.15547/ tjs.2017.02.001 
